This item was submitted to Loughborough's Research Repository by the author.

Items in Figshare are protected by copyright, with all rights reserved, unless otherwise indicated.

\title{
Non-technical barriers for decentralised energy and energy efficient buildings
}

PLEASE CITE THE PUBLISHED VERSION

http://dx.doi.org/10.1108/IJESM-03-2014-0001

\section{PUBLISHER}

(c) Emerald

\section{VERSION}

AM (Accepted Manuscript)

\section{PUBLISHER STATEMENT}

This work is made available according to the conditions of the Creative Commons Attribution-NonCommercialNoDerivatives 4.0 International (CC BY-NC-ND 4.0) licence. Full details of this licence are available at: https://creativecommons.org/licenses/by-nc-nd/4.0/

\section{LICENCE}

CC BY-NC-ND 4.0

\section{REPOSITORY RECORD}

Goodier, Chris I., and Ksenia Chmutina. 2019. "Non-technical Barriers for Decentralised Energy and Energy Efficient Buildings". figshare. https://hdl.handle.net/2134/25132. 


\title{
Non-Technical Barriers For The Implementation of Decentralised Energy: Learning From International Case Studies
}

\section{Chris I. Goodier ${ }^{a}$ and Ksenia Chmutina ${ }^{b}$}

${ }^{a}$ Loughborough University, School of Civil and Building Engineering, Loughborough, Leicestershire, LE11 3TU, UK. Email: c.i.goodier@lboro.ac.uk

${ }^{\mathrm{b}}$ Corresponding author. Loughborough University, School of Civil and Building Engineering, Loughborough, Leicestershire, LE11 3TU, UK. Email:k.chmutina@lboro.ac.uk. Tel.: +44 (0) 1509228526

\begin{abstract}
In order to meet its ambitious 2050 target of $80 \%$ carbon emission reduction, the UK needs to increase dramatically the wider uptake of decentralised energy (DE) systems. Many examples exist internationally of DE systems leading to enhanced carbon emissions reductions, including systems based not only on technological but also on more innovative policy, financial and social-economic approaches.

Following semi-structured interviews with key stakeholders, this paper compares four international cases. It demonstrates the variety and inter-connectivity of the non-technical barriers, and presents an evaluation of their impacts on the outcomes of the projects.

The main non-technical barriers are not necessarily financial, as is often believed; governance barriers, such as out-of-date regulations or unreliable partners can also play a critical role in a project's success or failure. Social barriers such as public apathy and misinformation often affect a project's operation. It is further hypothesised that non-technical barriers are often shaped by personal and/or organisational values related to consumption, abundance, trust, as well as control. Finally, recommendations are provided on overcoming these barriers with regards replicating similar DE projects in the UK context.
\end{abstract}

Keywords: decentralized energy; barriers; case study

\section{INTRODUCTION}

In recent years many countries worldwide have realised that in order to reach their emissions reduction targets, a shift has to be made towards more energy efficient practices and sustainable and renewable forms of energy [1;2]. The main drivers for the transition towards more decentralised energy (DE) are not only this necessity to reduce emissions, but also rising electricity demand and the price of fuel, liberalisation of the markets and increasing concern over energy security [3].

The current UK electricity system is highly centralised and relies heavily on fossil fuels. Most electricity is generated by large power plants connected to a high-voltage transmission network. This centralised model has delivered economies of scale and reliability, but it has significant disadvantages, such as transmission and distribution losses, high price of the system upgrade, as well as its (expensive) connection to the rural and remote areas [4; 5]. Many European and other countries are beginning a transition from a centralized and largely 
fossil-fuel and nuclear-based power systems toward a more decentralised power system relying to a larger extent on small-scale generation from renewable energy (RE) sources and Combined Heat and Power (CHP) units, allowing greater active participation of consumers by becoming producers themselves and/or by smarter demand response management of their own energy use [3].

The implementation of these approaches, however, is a long and complicated process that requires not only financial investment but also support from the authorities, community engagement and other factors that, if underestimated, can negatively affect the outcome of a project. A variety of economic, technical, cultural, behavioural and institutional barriers often slow down the uptake of DE initiatives and the potential maximisation of energy savings and emissions reduction.

This paper compares of four exemplar international cases in order to demonstrate the variety and inter-connectivity of the non-technical barriers involved during the implementation of DE projects and presents an evaluation of the impacts of these non-technical barriers on the eventual outcomes of the projects. A systematic perspective is presented, which takes into account the possible interactions between the various barriers and demonstrates that in order to remove some of these barriers, it is important to understand and account for their varied and interconnected nature.

\section{NON-TECHNICAL BARRIERS: TYPES AND DEFINITIONS}

It is commonly stated that new energy initiatives face barriers during their implementation, and sometimes also during their operation $[6 ; 7 ; 8]$. The diversity of potential barriers is comprehensive, varying from structural to behavioural [9]. A conventional view on success normally depends on a concept of the technical potential of the initiative, but it has to be taken into account that the realisation of the technical potential can often be slowed down, or lead to a failure by a lack of information, bureaucracy and other non-technical barriers.

In the context of energy initiatives, according to Verbruggen et al. [10:852], 'barriers' (synonyms: obstacle, hindrance, impediments) are 'man-made factors or attributes of factors that operate in between actual and potential RE development or use. They can be both intentional and unintentional. A barrier prevents or hinders action, impedes progress or achievement in realising potentials'. The IPCC [11: 810] define a barrier as 'any obstacle to reaching a goal, adaptation or mitigation potential that can be overcome or attenuated by a policy, programme, or measure. Barrier removal includes correcting market failures directly or reducing the transaction cost in the public and private sector by, for example, improving institutional capacity reducing risk and uncertainty facilitating market transactions, and enforcing regulatory policies'. These definitions characterise barriers as man-made and changeable. Interestingly however, the latter definition focuses on financial and regulatory aspects, and does not take into account social aspects, which, as will be discussed in section 5.3 , play an important role in many energy initiatives.

The types of non-technical barriers that prevent or slow down the success of energy initiatives can be technology specific, or specific to a country or a region $[7 ; 12 ; 13]$. 
Blumstein et al. [6] classify barriers as stable and transient. Stable barriers are deeply embedded in social and institutional establishments. They are resilient and, even when broken down, they tend to reappear in an altered form. Transient barriers are those caused by social inertia to new conditions, and can be modified. Painuly [7] states that barriers can be analysed at several levels, going from a broad category (e.g. financial barrier) to a more detailed a specific (e.g. high interest rate). Table 1 introduces groups of barriers and gives examples of each level.

Table 1: Barriers to energy initiatives (Adopted from Panuly, 2001 [7])

\begin{tabular}{|c|c|c|}
\hline \multicolumn{2}{|c|}{ Barrier category Barrier } & \multirow{2}{*}{$\begin{array}{l}\text { Barrier element examples } \\
\text { Inadequate information on products, } \\
\text { technology, costs, benefits; lack of } \\
\text { access/knowledge of assessment and } \\
\text { implementation requirements. }\end{array}$} \\
\hline Market failure & Lack of information and awareness & \\
\hline & Lack of competition & $\begin{array}{l}\text { Government monopoly; barriers created by } \\
\text { existing supplier }\end{array}$ \\
\hline & High investment requirements & $\begin{array}{l}\text { Economies of scale only at high investment } \\
\text { level }\end{array}$ \\
\hline \multicolumn{2}{|c|}{ Market distortionsSubsidies to conventional energy } & $\begin{array}{l}\text { Consumers pay below marginal costs; lower } \\
\text { taxed compared to RET; average cost pricing }\end{array}$ \\
\hline & Taxes on RETs & $\begin{array}{l}\text { High import duties; unfavourable direct/ } \\
\text { indirect taxation }\end{array}$ \\
\hline \multirow[t]{2}{*}{$\begin{array}{l}\text { Economic and } \\
\text { finance }\end{array}$} & Economically not viable & $\begin{array}{l}\text { High cost of product making it } \\
\text { uncompetitive; high implementation/ } \\
\text { adaptation costs; high user costs }\end{array}$ \\
\hline & High payback period & Low rates of return; inadequate incentives. \\
\hline \multirow[t]{3}{*}{ Institutional } & Lack of legal/ regulatory framework & $\begin{array}{l}\text { Unfavourable regulations; lack of } \\
\text { implementation of regulations }\end{array}$ \\
\hline & $\begin{array}{l}\text { Problems with realising financial } \\
\text { incentives }\end{array}$ & Complicated procedures; red tape; corruption \\
\hline & $\begin{array}{l}\text { Lack of institutions/ mechanisms to } \\
\text { disseminate information }\end{array}$ & $\begin{array}{l}\text { Lack of interest/ capacity in existing } \\
\text { institutions; lack of regulatory body. }\end{array}$ \\
\hline Social & Lack of social acceptance & $\begin{array}{l}\text { Technology seen as alien; lack of local } \\
\text { participation; preference for traditional } \\
\text { energy }\end{array}$ \\
\hline \multirow[t]{4}{*}{ Other } & Uncertain governmental policies & $\begin{array}{l}\text { Unsupportive policies; red tape; pack of } \\
\text { policies }\end{array}$ \\
\hline & Environmental & Ecological aspect; local pollution \\
\hline & High risk perception & $\begin{array}{l}\text { Uncertain new technologies; uncertain } \\
\text { benefits; high investment risks }\end{array}$ \\
\hline & Lack of infrastructure & $\begin{array}{l}\text { Problems related to availability of } \\
\text { infrastructure }\end{array}$ \\
\hline
\end{tabular}




\section{METHODOLOGY}

The case studies investigated here cover only a small example of the DE projects that exist worldwide. Selected from an initial group of 35 case studies, the main selection criteria for each case included:

- Applicability and uniqueness: i.e. the project/approach had not yet been applied in the UK or had only been applied on a very small scale, but possessed potential for application on a significant scale;

- Usefulness for investigating a variety of project characteristics and connectivities, and how these influence implementation and outcomes.

As well as these individual case selection criteria, the suite of cases was selected to include a range of different locations and scales, whilst being financially affordable for investigation.

In order to identify the non-technical barriers a preliminary desk study was firstly conducted to identify any project secondary data, references, websites, newspaper articles, reports or newsletters. Secondly, site visits for the authors were arranged, where possible, as this helps to visually observe and record, and hence obtain additional valuable insights regarding the project. Thirdly, interviews with the main project stakeholders took place in person (or via video-conference), to ascertain stakeholders' perspectives on the process of the project implementation - a crucial step in barrier identification as 'the perception of stakeholders on barriers may reveal the lacunae in existing policies and help in identification of measures to overcome the barriers' [7].

Three to four semi-structured interviews with a variety of project stakeholders were conducted for each case study (15 in total), covering five main aspects: governance, finance, technology, social aspects and the level of replicability. Questions about the experienced barriers and drivers in each aspect were asked, and the interviews were recorded, transcribed, coded and analysed using Nvivo 8. A coding framework including 23 top-level and 47 subcodes, based on the collected narratives and research questions - checked for reliability by independently coding two interviews by two different researchers in order to clarify and refine the code definitions. Codes relating to non-technical problems and barriers were analysed specifically for this paper.

\section{INTERNATIONAL CASE STUDIES DESCRIPTION}

The four case studies are summarised in Table 2. 
Table 2: Case study summary [14]

\begin{tabular}{|c|c|c|c|c|}
\hline & $\begin{array}{l}\text { Seawater } \\
\text { heating }\end{array}$ & tMorris Model & $\begin{array}{l}\text { Energy } \\
\text { Partnership }\end{array}$ & $\begin{array}{l}\text { Kungsbrohuset office } \\
\text { building }\end{array}$ \\
\hline Location & $\begin{array}{l}\text { The Hague, } \\
\text { Netherlands }\end{array}$ & $\begin{array}{l}\text { Morris County, New } \\
\text { Jersey, USA }\end{array}$ & Berlin, Germany & Stockholm, Sweden \\
\hline Technology/ area & Seawater heating & PV & Building retrofit & Eco-smart building \\
\hline Focus & Heating and cooling & Financing & Financing & Profit \\
\hline Date started & 1999 & 2009 & 1997 & 2010 \\
\hline Scale & 750 houses & $\begin{array}{l}19 \text { municipal buildings; } \\
\text { 3.2 MW }\end{array}$ & 1,400 buildings & 1 building, $27,000 \mathrm{~m}^{2}$ \\
\hline Investment & $€ 10 \mathrm{~m}$ & \$30 m (in bonds) & No initial investment & $€ 120 \mathrm{~m}$ \\
\hline $\begin{array}{l}\text { Funding body and } \\
\text { instigating party }\end{array}$ & $\begin{array}{l}\text { Vestia (housing } \\
\text { corporation) }\end{array}$ & $\begin{array}{c}\text { Morris County } \\
\text { Improvement Authority }\end{array}$ & $\begin{array}{c}\text { Berlin Energy Agency } \\
\text { (BEA) }\end{array}$ & Jernhusen \\
\hline $\begin{array}{l}\text { Energy / } \mathrm{CO}_{2} \\
\text { reduction }\end{array}$ & $\begin{array}{l}50 \% \text { of } \mathrm{CO}_{2} \\
\text { reduction }\end{array}$ & $\begin{array}{c}51,500 \text { MWh over } 15 \\
\text { years }\end{array}$ & $\begin{array}{c}\text { 60,400 tonnes of } \\
\mathrm{CO}_{2} / \text { year }\end{array}$ & $\begin{array}{l}50 \% \text { of energy } \\
\text { consumption } \\
\text { reduction }\end{array}$ \\
\hline Aim & Sustainability & $\begin{array}{l}\text { Energy savings and cost } \\
\text { reductions }\end{array}$ & $\begin{array}{l}\text { Energy savings and } \\
\text { cost reductions }\end{array}$ & Profit \\
\hline
\end{tabular}

\subsection{Seawater district heating system}

The City of The Hague has developed an innovative district heating (DH) concept consisting of a seawater central supply unit with a heat exchanger and heat pump unit that uses the nearby sea as a source of heating and cooling. The Hague and Vestia Housing Corporation partnered with Deerns to implement this energy source in the reconstruction of 800 highly energy efficient houses in Duindorp. The overall efficiency of the heat generation process is more than $50 \%$ greater than conventional high-efficiency boilers, while the cost to the residents is the same, and the energy yield produced by drawing heat from the sea results in a $50 \%$ reduction in $\mathrm{CO}_{2}$ emissions [15].

\subsection{Morris Model: PV for municipal buildings}

The Morris Model is a unique and cost-effective method of financing municipal RE projects for public facilities through low-interest bonds, traditional Power Purchase Agreements (PPA) and federal tax. It allows local government to receive access to RE at a price lower than they currently do, without any debt obligation. The Local Financial Board approved the Morris County Improvement Authority (MCIA) bonds of up to \$30 mln and the MCIA issued $\$ 21.6 \mathrm{mln}$ of debt at a $4.46 \%$ net interest cost with a county guarantee to fund 19 solar projects [16].

The MCIA has completed the first phase, installing 13,629 solar panels in 5 school districts and several county government facilities providing the County with 3.2 MW in clean energy and around \$3.8 m in annual savings [16] (see Table 3). The Morris Model has been replicated in Somerset and Union counties in New Jersey with several other counties in various stages of review.

\subsection{Berlin Energy Saving Partnership (BESP)}


The BESP is a energy performance contracting model based on transferring energy management of state-owned properties to a partner, who self-finances the modernisation of building infrastructure necessary to cut energy use and $\mathrm{CO}_{2}$ emissions. In return, the partner guarantees annual energy and cost savings for the state [17]. The current BESP includes schools, kindergartens, office buildings, swimming pools, theatre, universities and other municipal buildings. Implemented energy efficiency measures include refurbishment of heating and illumination, energy management as well as user motivation.

\subsection{Kungsbrohuset Office Building}

Kungsbrohuset is a 27,000 $\mathrm{m}^{2}$ 13-storey property next to Stockholm Central Station containing offices, shops, restaurants, cafes, and a hotel. The owner - Jernhusen - wanted to build a sustainable office building using readily available materials and technologies in order to create a development where the environment and energy-efficiency were central considerations. Indeed, the office space is primarily let to companies that want to boost their environmental image [18]. All the tenants are supported by an in-house expert who helps them to minimise their impact on the environment.

\section{THE ROLE OF NON-TECHNICAL BARRIERS IN PROJECT OUTCOMES}

Although financial barriers play an important role and may prevent a project from initiating or may slow development, the most emphasised barriers by the case study stakeholders were governance-related, with social barriers also having an important role (Table 3). For analysis, barriers were grouped into governance, financial, and social, and their impact on projects' outcomes were examined. Care has to be taken if attributing barriers to a single category, as they are often fashioned by several complex and interrelated factors. It is particularly challenging to categorise regulations-related barriers into individual categories as they incorporate both policy (governance) and financial barriers. Barriers were therefore divided into categories for simplification and analysis only, not as a definitive classification. Here barriers related to financial regulations were allocated into the governance barriers section.

Table 3: Summary of case study non-technical barriers

\begin{tabular}{|c|c|c|c|c|}
\hline & Morris Model & The Hague & BESP & Kungsbrohuset \\
\hline \multirow{5}{*}{ 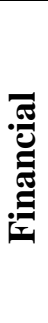 } & Financial constrains; & Lack of funding; & Financial constrains; & \multirow{5}{*}{$\begin{array}{l}\text { (originally) Not sure if } \\
\text { they can charge tenants } \\
\text { more on the basis of } \\
\text { 'being green'; } \\
\text { High payments to } \\
\text { contractors }\end{array}$} \\
\hline & \multirow{4}{*}{$\begin{array}{l}\text { High price of pre-screening } \\
\text { process }\end{array}$} & High initial costs; & Lack of subsidies; & \\
\hline & & $\begin{array}{l}\text { Need to subsidise energy } \\
\text { rates. }\end{array}$ & ESCOs cannot always & \\
\hline & & $\begin{array}{l}\text { Gap in the budget and high } \\
\text { financial risks; }\end{array}$ & & \\
\hline & & Long payback period & & \\
\hline
\end{tabular}




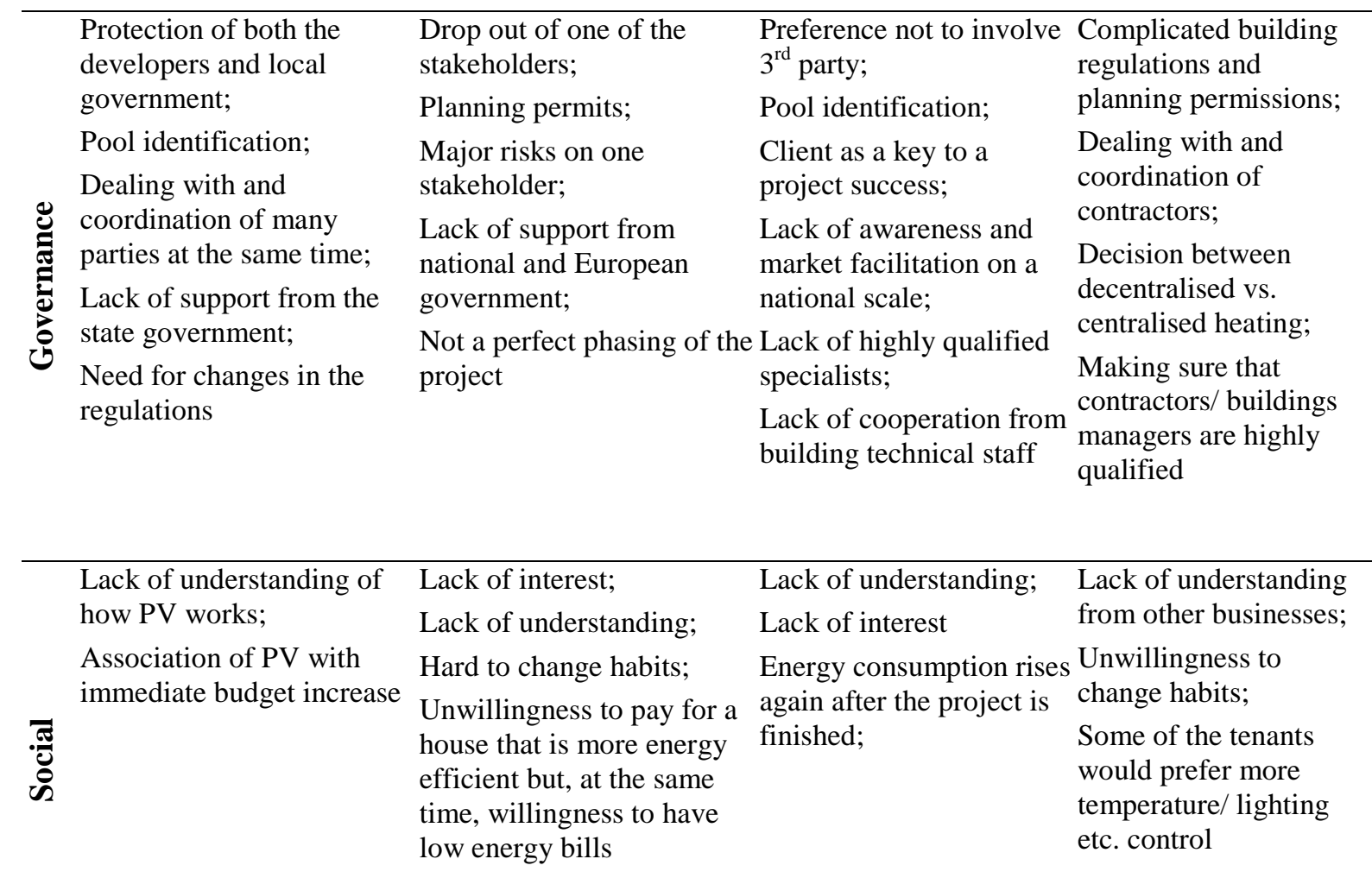

One way to consider the relative influence of and interest in these barriers is to consider how many stakeholders mentioned particular barriers during the interview process (Chai and Yeo, 2012). Stakeholders were questioned regarding the main barrier during the project implementation. Affirmative statements were followed with questions to elucidate greater detail on the particular barrier and how it was seen by the stakeholder to impede the project's success (Figure 1).

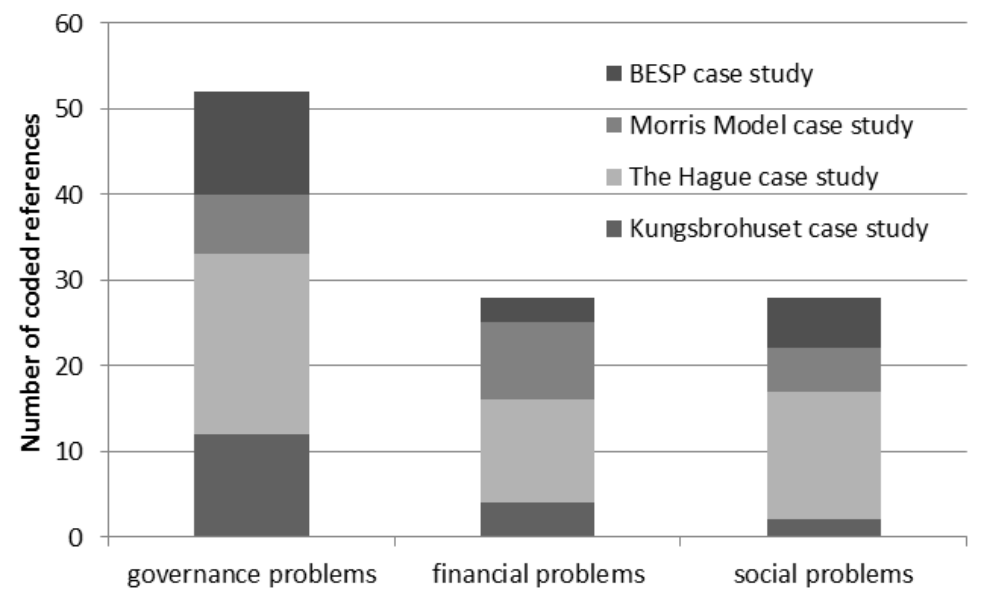

Figure 1 Number of coded barrier references

The majority of the interviewed stakeholders emphasised the role of governance barriers, particularly those related to policy and regulations. 


\subsection{Governance barriers}

There are many interpretations of governance (e.g. Never 2011 [19]; Blumstein 1980 [6]), but they mainly agree that governance consists of both structure and process, and involves public, public-private and private activities. Governance barriers identified in these four case studies can be divided into two main categories: policy process (i.e. government support, legislation), and stakeholder management (organisational aspect).

Although often discussed as the main drivers for DE initiatives (e.g. Alagappan et al., 2011 [20]; Foxon et al., 2005[12]), regulations was a barrier acknowledged across all four cases. In some cases, regulations were unfavourable: DE was disadvantaged compared to conventional energy sources; in other cases, regulations were uncertain, caused by short-term thinking and lack of decision-making. Many policies and regulations act as barriers due to the disparity between their theories and practice [13]. According to Blumstein et al. [6] this is evidence of conflicting goals, as was clearly shown in The Hague:

"It's [seawater plant site is] part of the coastal defence system against flooding - so that you can't do anything. You can't move any sand around between October and April. So if you start digging it's “No, you can't do that.” It's a tourist place which means that you are not allowed to work there during summer. From October to May you cannot, but from June till September you can’t either."

Environmental legislation thus slowed down implementation. Planning permissions were also often seen as an obstacle as they were inconsistent and over-complicated, and could negatively affect the timing of the project:

"I think the timing [Kungsbrohuset office building] was perfect. We did a large marketing campaign and it was completely based around the environmental performance of the building. We'd never do that again now. That time past [in Sweden]. Now it's expected that every major, prestige project in Stockholm or Gothenburg has good environmental performance that it's low energy usage and stuff like that”.

In three of the four cases government provided support for the instigating parties (or acted as an instigator in case of the BESP). The stakeholders admitted that the projects could benefit if the national government were involved:

"The only thing we probably would change is to see if the state could be more open, because they should be doing everything possible to make sure something like this is put into place. I think the regulations have to change” (Morris Model).

Involvement of national government could reduce the negative impact bureaucracy was having on the projects; although dealt with, it required extra effort and time from the stakeholders:

"You get so much bureaucracy. We had to go through all the red tape - which was a lot of red tape - because the State wants you to do this, yet it puts up all these barriers so you can't do it” (Morris Model).

Dealing with and coordinating parties involved was seen as a barrier that might create unexpected difficulties: 
"The main challenge is organisational I'd say: to get everybody to co-work with these goals of getting it as energy efficient as we wanted, to work with the environmental situation. Some people just said "Why are we going to do this? Can't we do it like we've always done it? Why do you want to make energy calculations every 4 months? You're not going to earn many per cent on that". Finally it comes to "Either you do as I tell you to do or we get rid of you." That was one of the hardest parts - to keep the line, to keep the focus on the target” (Kungsbrohuset).

In The Hague case, the stakeholder dropped out at the very last minute, highlighting that an unexpected change of mind and lack of commitment can lead to project failures if not addressed on time:

"Eneco didn't believe it [the system's efficiency] and they caused us quite some trouble because they made all kinds of objections against the system, and once we had solved their objections they came up with new ones. They retreated, so then we had this gap which was very bad. Really it was all arranged till the contract had to be signed. At that stage the guy who had to sign it picked up his pencil and said "No."”.

The implementation of the projects described in this paper required highly qualified specialists passionate about sustainability and demanded large capacities that were not always available:

"There are a lot of regions in Germany where you can do that [ESPs] and if we had been more active in this field we would maybe have the possibility to not do 3 tenders a year by maybe 5 or 10, but then of course with more staff. We try, but it's just my colleague and me and that's why it's also a question of capacity” (BESP).

Installation of many of the technologies needs to be carried out by highly trained specialists as the expectations on the performance will only be met if the installations are carried out properly. In addition to constant project supervision, the cost of qualified labour is also high, increasing the overall cost of the project.

\subsection{Financial barriers}

Fear of financial failure plays a major role in any business, although many understand that there is more to sustainability than just financial profit. The case studies faced a variety of financial barriers; however, they did not play a defining role and did not lead to project failure. All of the financial barriers presented in Table 3 were addressed.

The common financial barrier was financial constraint: for Morris Model, only \$30m was available for bonds; in case of the BESP, only certain energy efficiency measures with low payback period could be performed. This however, did not affect the project outcomes. Financial constraints were put into place by the project developers in order to protect solar developers (Morris Model) and ESCOs (BESP) from financial failure and ensure adequate financial returns and profit.

Lack of finance was also named as a barrier: having better access to capital would allow the project to achieve better economies of scale or to be taken to a new level e.g. the BEA is considering BESP Plus in order to take energy efficiency measures further and offer the 
clients energy saving solutions with higher payback periods, such as insulation and windows replacement:

"We have the contract for this and we want to do this, but we still have to find the financing. The ESCOs cannot finance this”.

Lack of funding in The Hague was caused by stakeholder drop out, which created a 25\% gap in the project budget, which was eventually covered by the project owner (Vestia) and the City of The Hague. Vestia agreed to carry high financial risks in case of project failure; in addition, the scale of the project was reduced from 1,000 houses to 750 houses, which led to a longer than expected payback period. Financial profitability was not, however, the aim of this project, but to prove that it is possible to make heating for the Duindorp area sustainable using a locally available source - sea water.

Financial barriers did not play a central role in these cases and often presented possibilities for improvement rather than failure. More innovative energy initiatives however, do require higher initial investment and a strong financial background as their performance in new and different applications is often unknown.

\subsection{Social barriers}

Social barriers were obstacles created not only by the users in these cases, but also by those affected, such as surrounding communities and people living in the area.

The main social problem described in all four cases was a lack of understanding of how the technology worked, which can consequently affect performance, and in some cases lead to rising energy consumption:

"If the building owner doesn't have the technical stuff to take care of that or he doesn't know about energy management, of course the energy consumption then starts to rise up again” (BESP).

Lack of understanding can lead to other problems such as lack of interest:

"People with low income and low education, they don't understand exactly how to use all this kind of stuff and they don't care about it. They care about other stuff - what the neighbours do and how to get beer or something” (The Hague).

Although the project stakeholders had been using various methods for raising social awareness, such as information evenings, brochure distribution etc. it is difficult to evaluate the impact of these campaigns and whether the level and understanding among the community had been improved.

Consumers were also more concerned about initial costs rather than annual savings:

“They didn't really believe that we weren't spending any money. [They] immediately associated the cost of the solar project with a potential budget increase even though we kept telling them it wasn't the case. So it required me to do more of a line-by-line budget description for the community so that they trusted and believed that this was not embedded in our budget” (Morris Model). 
Although stakeholders tried to overcome this barrier by explaining to users how systems work, none of the projects had behaviour change as their aim and their campaigns were run for educational purposes only, with the plan that the awareness would encourage behaviour change towards more sustainable behaviour. In addition, although the information is provided, it might not be used effectively due to prevailing habits. Habits played a crucial role in creating social barriers:

"You don't put some carpet on it which is very [thermally] resistant. You have to be aware of what you put on it because when you do something like that on the floor it doesn't work [due to the under-floor heating]” (The Hague).

Indeed, 'energy-consuming behaviours are often guided by habits and that deeply ingrained habits can become counter-intentional” [21: 1104]. Therefore, it is important to make users aware of their habits and convince them that change of habits could lead to financial as well as non-financial benefits, such as thermal comfort. The awareness raising campaigns should incorporate feedback that informs and motivates based on real practical examples and behaviours, rather than simply providing information that may not be of interest.

Users often view energy efficiency and RE technologies as something new and foreign, therefore associated with discomfort and/ or sacrifice rather than with energy consumption and cost reduction. This often leads to decisions which may not be economically rational but are the matter of habit or lack of interest (e.g. Bergman and Eyre, 2011 [22]; Dias et al., 2004 [23]). This conflict highlights the importance of taking into account habits, knowledge and personal interest, rather than assuming that consumers will behave within economic rationality.

\section{DISCUSSION}

Although categorised into financial, governance and social barriers, the actual barriers experienced in these cases do not fit distinctively into one category and have to be analysed systematically. Barriers experienced frequently include elements of several categories, e.g. the large size of the domestic boilers in The Hague, generally seen as a technical barrier; but also a social barrier, as their size created dissatisfaction amongst the users, as they were not willing to 'sacrifice' sufficient space within their houses. This was however, even more complex, initiating due to a lack of project finance; but perpetuating due to a lack of end user information hence understanding and acceptance regarding smaller boilers, and a difficulty in the supply of adequate boilers.

Some of the barriers, such as governmental policies, can also either complicate the process of new energy initiative implementation and create a further barrier, or can help foster project implementation and hence act as a driver, a good example being the Morris Model, the creation of which was encouraged by the legislation which showed support towards PV market development. Unlike the Morris Model however, regulations in The Hague slowed down the process of project realisation, contributing towards the drop out of one of the stakeholders and hence increased financial risk. 
Some barriers are also tightly interrelated whereas others are more independent and hence have little impact on one other e.g. the interrelated barriers in The Hague (Figure 2).

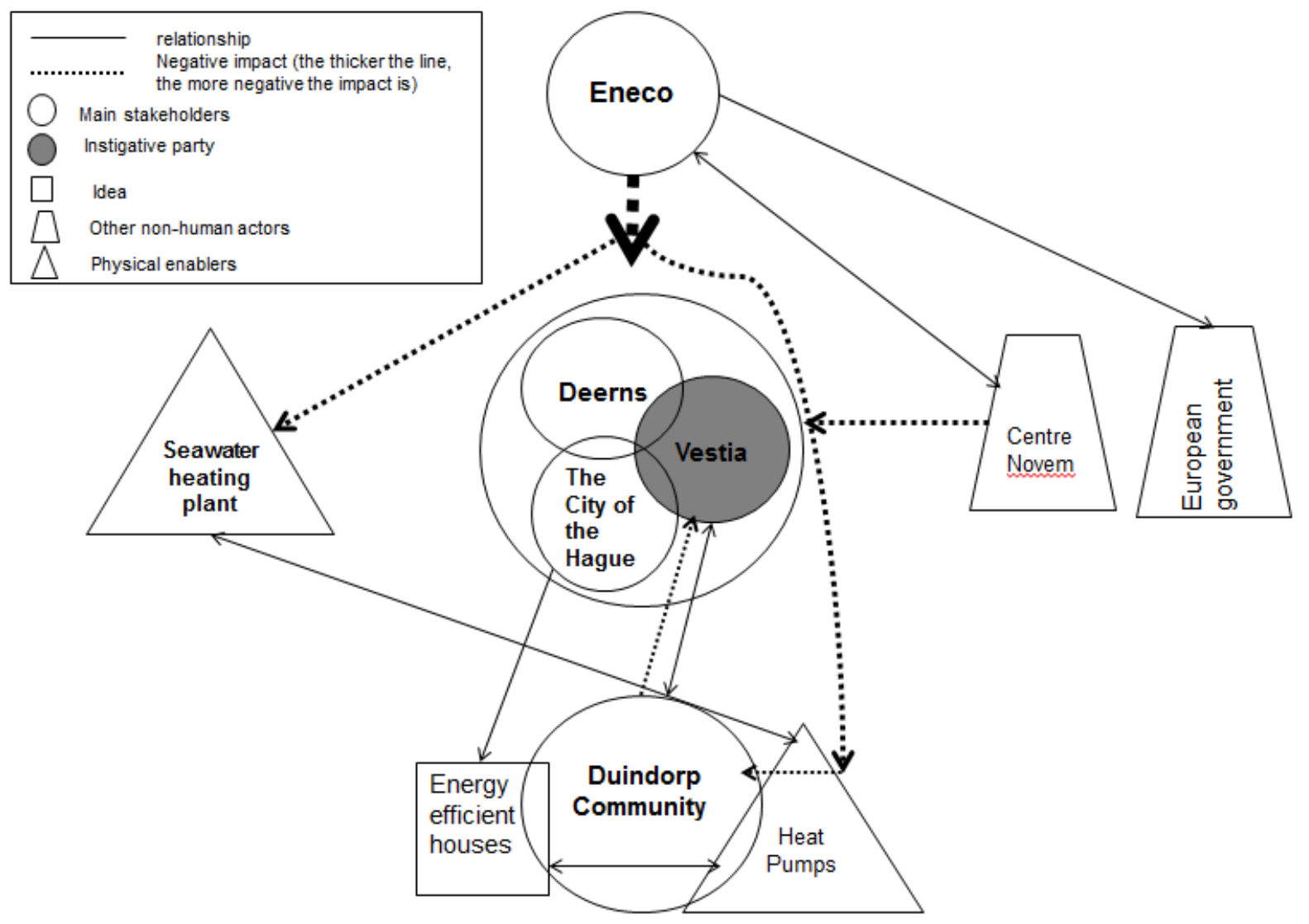

Figure 2: Schematic presentation of the inter-related barriers in The Hague case study ${ }^{1}$

The original - and the most crucial barrier - was the withdrawal of a key stakeholder (governance barrier). This led to a $25 \%$ budget deficit (financial barrier), and the remaining stakeholders invested significant effort in trying to find a financial substitute to cover this shortfall e.g. by inviting the national government to take part in the project. However, the stakeholder leaving had a negative effect on the projects' reputation, as it was believed that it was based on the technical impossibility of the project, and no one else wanted to take the risk (governance barrier). The financial gap was eventually covered by the main stakeholder and instigator of the project (Vestia) and the City of The Hague; requiring financial sacrifices on the project's technical aspects, resulting in the installation of less efficient domestic boilers, which consequently became the main reason for end user complaints (social barrier). A 'domino effect' thus resulted, and although all the barriers were to some extent overcome, the outcome of the project might have been different if the first - governance barrier - had not occurred.

Although the impact of financial barriers was not as dramatic in these cases as is frequently described (Brown et al., 2008; Painuly 2001), innovative energy initiatives often require high

\footnotetext{
${ }^{1}$ The thickness of the dotted line relates to the level of impact; the thicker the line, the more negative the impact was.
} 
initial investment and involve not insignificant financial risk. Risk (although not stated directly) was implied as a financial barrier in all of the case studies, e.g.:

"Any technology, any method, anything that we have done here is found somewhere else in the world. We don't want to be first with anything because we don't want to take the risk" (Kungsbrohuset).

While the benefits of energy savings and carbon reductions can be evident for both stakeholders and users, risk and uncertainty are an inherent part of innovative initiatives. Innovation in energy initiatives has three major problems that lead to financial risks: 1) longterm financial commitment in a not necessarily stable economic situation; 2) reliance on the future prediction of the performance of the innovative approach; 3) and uncertainty of how the performance can be affected by the users or other factors, which cannot be accounted for (Foxon, 2005). Risk as a barrier is normally foreseen in innovative and unique projects like these however, and its impact is usually evaluated during the project planning and evaluation stage. In the cases presented here, financial barriers were connected to governance barriers (e.g. financial constraints, drop-out of stakeholder) and could have been minimised if the governance barriers had been absent. In terms of overcoming financial barriers, rather than eliminating innovative and expensive technology in order to reduce the initial cost and risk of the project, a more 'cost-effective' scheme similar to Morris Model could be applied; these schemes however usually require government support, as well as stakeholders interested not only in profitability, but also in sustainability.

These case studies also demonstrate that governance barriers can have a significant impact on project implementation, mainly because they affect the timing of the project. Timing is crucial as slight changes in the economic/business environment can have a significant bearing on an investment decision. Governance barriers require action not only from stakeholders but also from government, both local and national. Bearing in mind the obstacles created by the regulations in the cases examined here, the regulatory barriers could be mitigated by more transparent and simplified permission-obtaining procedures; enhancement of co-ordination, particularly within the different regulation authorities during the overall procedure of the project implementation; and improvement of overall public acceptability, as our findings suggest.

Del Rio [24] emphasised that dissemination of information regarding new projects plays an important role in their widespread adoption and acceptance. Various engagement approaches were applied in the four cases investigated in order to overcome social barriers: including information evenings, publications, leaflets and consultations. Upon deeper analysis however, these measures do not necessarily overcome this barrier due to a lack of understanding of, and prevailing of, habits. Social barriers do not usually affect the implementation of projects, but start playing an important role during the operational phase, often leading to lower project performance and, consequently, to lower project acceptance and hence complaints from users. This can consequently negatively affect the project's reputation, as word-ofmouth frequently plays a significant role in new and innovative style projects, enforcing the adage 'good news travels fast, bad news travels faster'. In order to overcome social barriers, it is important to offer as much support to users as possible and to explain in their terms the 
link between new technologies and potential and actual financial and non-financial benefits. Reddy and Painuly [8] also suggest that users often take advice of other users over that of technical experts, therefore exemplar cases disseminated by the users themselves rather than their instigators should be encouraged and fostered. It is also important to make users aware of and understand their habits and follow-on consequences, as actually changing the behaviour of the users - that all the case studies studied here were trying to target in one way or another - will not be achieved unless the users themselves as a cohort are strong in their belief and commitment to sustainability, which is rarely the case. Finally, it should also be remembered that users can play an important role in technology development [25] and technical improvement can often be realised through building upon users' feedback.

\section{CONCLUSIONS}

Any significant change, such as a shift to DE, frequently faces a variety of diverse and interconnected barriers. Despite this, and the unfavourable economic situation in recent years, all the cases examined here were considered a success (see [26] for further discussion on success).

There is often a lack of consideration regarding barrier interconnectivity. Considering them in isolation provides only part of the story, a situation often ignored in contemporary guidance, with recommendations proposed for a single barrier often ignoring its possible connectivity with other related barriers. Understanding these complex relationships is crucial in making effective recommendations.

The main barriers identified in the cases investigated here were: funding and financing; unfavourable administrative conditions; lack of acceptance and perception; and organisation and management constraints. Although in these cases these barriers did not lead to project failure, they did have adverse impacts. Governance barriers in particular had the greatest negative impact on project implementation, particularly regarding overall costs and financing, as well as time delays.

The uniqueness of the barriers faced in the different cases emphasises the fact that projectspecific deployment policies and programs were vital. In contrast however, more general actions agreed on a (higher) international level may be more efficient in removing common barriers in a broader, more systematic fashion in ways that could significantly accelerate and expand an increased number and variety of DE projects. Indeed, this tension between highly specific and general policy interventions requires on-going careful attention and deliberation.

These case studies offered a significant learning experience for the parties involved, whilst also presenting a high potential for replication and scaling up. In order to develop strategies to overcome the barriers explored here, it is prudent to consider the wider casual chain of connected barriers rather than solitary barriers in isolation, as it allows the identification and examination of the criticality of the particular barrier on the wider outcome of the project.

Acknowledgements: This research was undertaken as a part of the CLUES (Challenging Lock-in through Urban Energy Systems) project supported by finding from the EPSRC under the SUE programme (Grant ref.: EP/1002170/1). We would like to thank our project colleagues for their helpful comments. 


\section{References}

[1] Brown MA, Chandler J, Lapsa MV and Sovacool BK. Carbon Lock-in: Barriers to deploying climate change mitigation technologies. Report for the U.S. Department of Energy 2008. Available at http://www.ornl.gov/sci/eere/PDFs/ORNLTM-2007-124_rev200801.pdf (accessed 15/10/2013).

[2] Rydin Y, Turcu C, Chmutina K, Devine-Wright P, Goodier C, Guy S et al. Urban Energy Initiatives: the implications of new urban energy pathways for the UK. Network Industries Quarterly 2012; 14: 2-3.

[3] European Parliament's Committee on Industry, Research and Energy (ITRE). Decentralised Energy Systems. IP/A/ITRE/ST/2009-16. $2010 . \quad$ Available at www.europarl.europa.eu/document/activities/cont/201106/20110629ATT22897/20110629ATT22897EN.pdf (accessed 15/10/2013).

[4] Allen SR, Hammond GP and McManus MC. Prospect for and barriers to domestic micro-generation: A United Kingdom perspective. Applied Energy 2008; 85(6): 528-44.

[5] Martin J. Distributed vs. centralized electricity generation: are we witnessing a change of paradigm? HEC Paris. 2009. Available at http://www.vernimmen.net/ftp/An_introduction_to_distributed_generation.pdf (accessed on 15/10/2013).

[6] Blumstein C, Krieg B, Schipper L and York C. Overcoming social and institutional barriers to energy conservation. Energy 1980; 5 (4): 355-71.

[7] Painuly JP. Barrier to renewable energy penetration: a framework for analysis. Renewable Energy 2001; 24 (1): 73-89.

[8] Reddy S and Painuly JP. Diffusion of renewable energy technologies - barriers and stakeholders perspectives. Renewable Energy 2004; 29 (9): 1431-47.

[9] Shove E. Gaps, barriers and conceptual chasms: theories of technology transfer and energy in buildings. Energy Policy 1999; 26 (15): 1105-12.

[10] Verbruggen A, Fischedick M, Moomaw W, Weir T, Nadai A, Nilsson LJ et al. Renewable energy costs, potentials, barriers: Conceptual issues. Energy Policy 2010; 38 (2): 850-61.

[11] IPCC. Climate Change 2007: the Physical science basis - summary for policymakers. Geneva. IPCC Secretariat. 2007. Available at http://www.ipcc.ch/pdf/assessment-report/ar4/wg1/ar4-wg1-spm.pdf (accessed on 15/10/2013).

[12] Foxon TJ, Gross R, Chase A, Howes J, Arnall A and Anderson D. UK innovation systems for new and renewable energy technologies: drivers, barriers and system failures. Energy Policy 2005; 33 (16): 2123 -37.

[13] Chai KH and Yeo C. Overcoming energy efficiency barriers through systems approach - A conceptual framework. Energy Policy 2012; 46: 460-72.

[14]. Chmutina K, Goodier CI. Assessment of innovative international urban decentralized energy systems: case study examples. In: Proceedings of the International Conference on Technology transfer and Renewable Energy 2013, Mauritius, pp. 501-16 (ed: W.Leale). https://dspace.lboro.ac.uk/2134/10254.

[15] Goodier CI, Chmutina K, Poulter E and Stoelinga P. The potential of seawater heating systems in the UK: examples of The Hague seawater district heating and Portsmouth Ferry Port. ICE Energy 2012. DOI: http://dx.doi.org/10.1680/ener.12.00016. https://dspace.lboro.ac.uk/2134/11071.

[16] Chegwidden WJ, Pearlman SB and Scerbo RJ. A county shares the light with local governments. New Jersey Municipalities 2010; unknown.

[17] Chmutina K, Goodier CI and Berger S. The potential of Energy Saving Partnerships in the UK. ICE Engineering Sustainability 2013. DOI: 10.1680/ensu.12.00015 
[18] Jernhusen. Kungsbrohuset: Is your company ready? 2012. Available at http://www.kungsbrohuset.se/Documents/ENG_KBH-broschyr_NYlogga.pdf (accessed on 15/10/2013).

[19] Never B. Integrating energy and climate change in South Africa: drivers, barriers and the shadow of hierarchy. The Governance of Clean Development Working paper series 2011. University of East Anglia. Available at http://www.tyndall.ac.uk/sites/default/files/gcd_working_paper_013_-_never_2011.pdf (accessed on $15 / 10 / 2013)$.

[20] Alagappan L, Orans R and Woo CK. What drives renewable energy development? Energy policy 2011; 39 (9): 5099-104.

[21] Marechal K. Not irrational but habitual: the importance of "behavioural lock-in” in energy consumption. Ecological Economics 2011; 69 (5): 1104-14.

[22] Bergman $N$ and Eyre N. What role for microgeneration in a shift to low carbon domestic energy sector in the UK? Energy Efficiency 2011; 4 (3): 335-53

[23] Dias RA, Mattos CR and Balestieri JAP. Energy education: breaking up the rational energy use barriers. Energy Policy 2004: 32 (11): 1339-47.

[24] Del Rio P and Unruh G. Overcoming the lock-out of renewable energy technologies in Spain: The cases of wind and solar electricity. Renewable and Sustainable Energy Reviews 2007 (7); 11: 1498-513.

[25] Ornetzeder M and Rohracher H. User-led innovations and participants processes: lessons from sustainable energy technologies. Energy Policy 2005; 34 (2): 138-50.

[26] Chmutina K, Sherriff G and Goodier CI. Success in international decentralised urban energy initiatives: a matter of understanding? Local Environment 2013. DOI: 10.1080/13549839.2013.805739 